\title{
Efeitos da terapia fotodinâmica e de uma única aplicação de laser de baixa potência em bactérias in vitro \author{
laser irradiation on bacteria in vitro
} \\ Effects of photodynamic therapy and of a sole low-power
}

\author{
Rogério Gubert Benvindo, Graziela Braunn, Alberito Rodrigo de Carvalho, Gladson Ricardo Flor Bertolini ${ }^{4}$
}

1 Fisioterapeuta Especialista em Fisioterapia TraumatoOrtopédica

2 Farmacêutica bioquímica; Profa. Ms. do Laboratório de Microbiologia da Unioeste (Universidade Estadual do Oeste do Paraná, Campus Cascavel, PR)

3 Fisioterapeuta Especialista em Fisioterapia TraumatoOrtopédica; Prof. do Laboratório de Estudo das Lesões e Recursos

Fisioterapêuticos, Unioeste

4 Fisioterapeuta; Prof. Ms. do Laboratório de Estudo das Lesões e Recursos

Fisioterapêuticos, Unioeste

ENDEREÇO PARA

CORRESPONDÊNCIA

Gladson R. F. Bertolini

Clínica de Fisioterapia da

Unioeste

R. Universitária 2069 Jardim

Universitário

85819-110 Cascavel PR e-mail:

gladson_ricardo@yahoo.com.br
Resumo: O laser de baixa potência vem sendo usado para acelerar a cicatrização em úlceras de pressão devido a seus efeitos cicatrizante, antiinflamatório, antiedematoso e analgésico. No entanto, não há consenso quanto a seu efeito em úlceras infectadas. O objetivo deste estudo foi verificar o efeito bactericida da laserterapia e da terapia fotodinâmica (TFD) com laser de baixa potência, InGaP, $670 \mathrm{~nm}$, em doses de 2, 4 e $6 \mathrm{~J} / \mathrm{cm}^{2}$, em bactérias gram-positivas e gram-negativas in vitro. Foram preparadas 32 placas de Petri com bactérias, 16 com Pseudomonas aeruginosa e 16 com Staphilococcus aureus. Aleatoriamente dividiu-se cada grupo em oito subgrupos (duas placas cada): três subgrupos tratados só com laserterapia, em doses de $2 \mathrm{~J} / \mathrm{cm}^{2}, 4 \mathrm{~J} / \mathrm{cm}^{2}$ e $6 \mathrm{~J} / \mathrm{cm}^{2}$; três subgrupos tratados com TFD, em doses de $2 \mathrm{~J} / \mathrm{cm}^{2}, 4 \mathrm{~J} / \mathrm{cm}^{2}$ e $6 \mathrm{~J} / \mathrm{cm}^{2}$; um tratado apenas com fotossensibilizante (azul de metileno a 0,1 $\mu \mathrm{g} / \mathrm{ml}$ ); e um subgrupo não tratado (controle). Os subgrupos laser e TFD foram irradiados uma única vez e incubados por 24 horas. Os outros dois subgrupos não receberam irradiação. As culturas foram analisadas visualmente para verificação ou não do halo de inibição. Em todos os subgrupos, de ambas as bactérias, não foi observado qualquer halo de inibição nem de crescimento. Conclui-se que a terapia a laser e a fotodinâmica de baixa potência (InGaP, $670 \mathrm{~nm}$ ) não produziram efeitos bactericidas e/ou bacteriostáticos, tampouco tendo havido efeito bioestimulante sobre as bactérias.

Descritores: Bactérias/efeitos de radiação; Fotoquimioterapia/utilização; Terapia a laser de baixa intensidade

ABSTRACT: Low-level laser therapy has been used to speed up healing process of pressure ulcers due to its antiinflammatory, analgesic, anti-edematous, and scarring effects. However there is no consensus on its effect on infected ulcers. The aim of this study was to verify the bactericidal effect of lowlevel laser therapy (InGaP, $670 \mathrm{~nm}$ ) and photodynamic therapy (PDT) at 2, 4 and $6 \mathrm{~J} / \mathrm{cm}^{2}$ doses, onto gram-negative and gram-positive bacteria in vitro. Thirty two Petri plates were prepared, 16 with Pseudomonas aeruginosa and 16 with Staphilococcus aureus, and divided into eight subgroups each: three subgroups treated with $2 \mathrm{~J} / \mathrm{cm}^{2}, 4 \mathrm{~J} / \mathrm{cm}^{2}$, and $6 \mathrm{~J} / \mathrm{cm}^{2}$ laser; three subgroups treated with $2 \mathrm{~J} / \mathrm{cm}^{2}, 4 \mathrm{~J} / \mathrm{cm}^{2}$, and $6 \mathrm{~J} / \mathrm{cm}^{2}$ PDT; one treated solely with photosensitiser; and a non-treated (control) subgroup. Laser and PDT groups were irradiated once and incubated for 24 hours; the other two subgroups underwent no irradiation. Cultures were visually analysed in search of inhibition haloes. In all subgroups, for both bacteria, no inhibition or growing signs could be detected. Hence neither low-level laser or PDT (InGaP, 670 $\mathrm{nm}$ ) produced any bactericidal or bacteriostatic effect, nor any biostimulation effect, onto analysed bacteria.

KEY worDs: Bacteria/radiation effects; Laser therapy, low level; Photochemotherapy/ utilization
APRESENTAÇÃO

maio 2007

ACEITO PARA PUBLICAÇÃO

dez. 2007 


\section{INTRODUÇÃO}

Infecções causadas por Pseudomonas aeruginosa e Staphilococcus aureus estão entre as de maior ocorrência em hospitais e são as duas bactérias mais freqüentes em úlceras de pressão ${ }^{1,2}$. Tais infecções podem atrasar ou impedir o processo de cicatrização de uma ferida, bem como debilitar o estado geral do paciente levando-o, em casos mais extremos, à morte ${ }^{3-5}$. Feridas infectadas, em especial as úlceras de pressão, constituem uma complicação clínica importante, com possível incidência em até $28 \%$ da população internada em hospitais, gerando gastos anuais estimados em mais de 1 bilhão de dólares com diagnóstico e tratamento ${ }^{6}$.

A fisioterapia tem um papel na prevenção e tratamento de tais feridas, lançando mão de recursos físicos como o laser, para acelerar o processo de cicatrização dos tecidos envolvi$\operatorname{dos}^{7,8}$. Entretanto, a infecção da ferida constitui uma barreira à aplicação da terapia laser, pois acredita-se que a radiação pode causar aumento do crescimento bacteriano ${ }^{9}$.

Embora alguns estudos comprovem o efeito bactericida e/ou bacteriostático do laser, permanece ainda o paradoxo de estudos que verificaram aumento do crescimento bacteriano (principalmente de cepas de Escherichia coli $)^{10-13}$. Nussbaum et al. ${ }^{14}$, ao irradiar com $660 \mathrm{~nm} P$. aeruginosa, E. coli e $S$. aureus, observaram efeitos marginais no crescimento bacteriano $(p=0,07)$, com tendência geral de diminuir o crescimento. Porém, em outros comprimentos de onda (630 e $810 \mathrm{~nm}$ ) houve aumento geral no crescimento; apenas com 905 nm o crescimento não foi significativo. Relatam ainda que, sobre o Staphylococcus aureus, não houve efeito geral no crescimento.

Em outro estudo, os mesmos autores $^{15}$ analisaram os efeitos de $810 \mathrm{~nm}$ sobre as mesmas bactérias, alterando a forma de entrega do laser. Ao avaliar as formas de entrega pulsada e contínua, obtiveram resultados bastante controversos, mas relatam que o crescimento bacteriano aumentou no modo contínuo apenas com $1 \mathrm{~J} / \mathrm{cm}^{2}$, independente da espécie. Variando a modulação de freqüência e dose, induziu-se intensamente o crescimento de Pseudomonas aeruginosa; sobre Staphylococcus aureus, o efeito ocorreu principalmente em altas freqüências (1000 e 3800 Hz); e sobre Escherichia coli, apesar de em $1000 \mathrm{~Hz}$ ter ocorrido aumento de $138 \%$, não houve efeitos estatisticamente significativos.

Postula-se que o efeito bactericida da laserterapia de baixa potência (efeito direto na membrana bacteriana) ocorra em virtude da absorção de fótons por cromóforos endógenos (dentro da bactéria), com concomitante produção de moléculas altamente reativas e citotóxicas, que provocam a ruptura da membrana e morte bacteriana $^{11}$.

A terapia fotodinâmica (TFD) é usada pela medicina no tratamento alternativo para tumores superficiais pequenos. Tal técnica consiste na administração de um corante (fotossensibilizante) com posterior aplicação de radiação laser. O poder bactericida da TFD pode ser explicado pela escassa atenuação do laser em virtude da otimização da absorção gerada pelo corante, bem como pela produção de radicais livres (citotóxicos) pelo próprio corante, causando lesão na parede bacteriana ${ }^{16-18}$.

O aumento da resistência das bactérias às drogas antibióticas gera a necessidade de desenvolver novos meios bacteriostáticos e bactericidas que colaborem com a terapêutica de indivíduos infectados. No entanto, há poucos trabalhos que forneçam dados práticos sobre o efeito bactericida da TFD e da laserterapia de baixa potência, não havendo consenso nos resultados dessas terapias em feridas. Os estudos sobre o efeito bactericida de tais terapias usam vários tipos de laser, com diferentes comprimentos de onda, potência e doses de irradiação, e nenhuma recomendação pode ser feita a respeito do tipo de laser e comprimento de onda ótimo para tal terapia $^{6}$.
O objetivo deste trabalho foi analisar o efeito bactericida in vitro da terapia fotodinâmica e da laserterapia de baixa potência (InGaP, 670 nm) sobre as principais bactérias presentes em úlceras de pressão infectadas, em bactérias gram-positivas e gramnegativas, com doses de 2, 4 e $6 \mathrm{~J} / \mathrm{cm}^{2}$, buscando a padronização de uma dosagem para o tratamento de tecidos infectados.

\section{METODOLOGIA}

Este estudo foi desenvolvido no Laboratório de Microbiologia da Universidade Estadual do Oeste do Paraná (Unioeste).

\section{Culturas bacterianas}

Foram utilizadas bactérias da bacterioteca do Laboratório descritas na literatura como causadoras de infecção em úlceras de pressão. Cada grupo de bactérias foi diluído em solução fisiológica estéril, para obter a escala de turbidez semelhante à escala 0,5 de MacFarland (equivalente a 1,5 x 108 UFC/ml).

Para a amostra tratada com terapia fotodinâmica (TFD) foi acrescido 0,1 $\mu \mathrm{g} / \mathrm{ml}$ de corante (azul de metileno) às bactérias nos tubos de ensaio. Dentro de 15 minutos procedeu-se à semeadura, introduzindo um cotonete (swab) estéril na suspensão (retirando o excesso pressionando na lateral do tubo) e estriando toda a superfície de uma placa de Petri com 50 mm de diâmetro, contendo o meio de cultura Ágar Mueller-Hinton (AMH) por duas vezes, girando a placa a $90^{\circ}$ entre uma estriação e outra para obter uma inoculação homogênea.

\section{Equipamento}

Foi utilizado o equipamento Laser, InGaP, da marca Bioset ${ }^{\circledR}$, modelo Physiolux Dual, com os seguintes parâmetros: saída de $30 \mathrm{~mW}$, comprimento de onda $670 \mathrm{~nm}$, feixe de luz único de cor vermelha, emissão contínua e direta. $\mathrm{O}$ aparelho foi aferido previamente ao início dos trabalhos. 
Amostra

Foram preparadas 32 placas de Petri com meio de cultura $\mathrm{AMH}$, onde foram semeadas as bactérias Pseudomonas aeruginosa (bactérias gram-negativas) (16 placas) e Staphilococcus aureus (bactérias gram-positivas) (16 placas), a partir de cepas padrão.

Aleatoriamente dividiu-se cada grupo em oito subgrupos (com duas placas cada), a saber: a) três subgrupos tratados somente com laserterapia, com dosimetrias em $2 \mathrm{~J} / \mathrm{cm}^{2}, 4 \mathrm{~J} / \mathrm{cm}^{2}$ e $6 \mathrm{~J} / \mathrm{cm}^{2}$; b) três subgrupos tratados com TFD, com dosimetrias em $2 \mathrm{~J} / \mathrm{cm}^{2}$, $4 \mathrm{~J} / \mathrm{cm}^{2}$ e $6 \mathrm{~J} / \mathrm{cm}^{2}$; c) um subgrupo tratado somente com fotossensibilizante - azul de metileno a 0,1 $\mu \mathrm{g} / \mathrm{ml}$; d) e um subgrupo não tratado (controle).

As amostras dos subgrupos tratados com laserterapia e com TFD foram irradiadas, uma única vez, pela técnica por zona ${ }^{19,20}$ (visto a saída do equipamento produzir radiação divergente), sem contato, com irradiação na região central da placa, área de irradiação na placa de cultura de $1 \mathrm{~cm}^{2}$ (distância padronizada e mantida pelo suporte do laser, Figura 1).

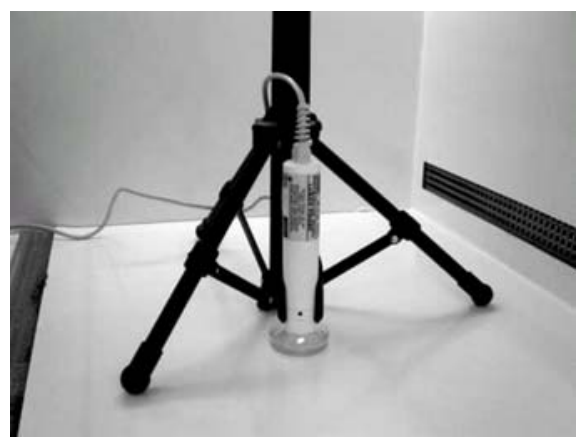

Figura 1 Ilustração do uso da radiação laser sobre a placa de Petri cultivada com bactérias, com área de irradiação predeterminada

Os tempos de irradiação foram estabelecidos levando-se em conta a dose desejada, área a ser irradiada e potência do laser $^{19,20}$, sendo que o tempo utilizado foi de $34 \mathrm{~s}$ para cada $1 \mathrm{~J} / \mathrm{cm}^{2}$, com diâmetro de saída do feixe de $0,09 \mathrm{~cm}^{2}$.
As amostras do grupo tratado somente com fotossensibilizante e do grupo controle foram submetidas aos mesmos procedimentos de irradiação, porém com o aparelho laser desligado (simulacro).

Após irradiação ou simulacro, as placas foram incubadas por 24 horas em estufa aeróbia, com temperatura máxima aferida em $37^{\circ} \mathrm{C}$. Após incubação, realizou-se a medição da área de inibição do crescimento bacteriano, com auxílio de um gabarito especialmente preparado (folha de papel milimetrado).

Os resultados foram considerados pela verificação da existência do halo de inibição. Os halos de inibição foram interpretados como resistente, intermediário ou sensível. Todas as amostras foram manuseadas em área livre de contaminação (fluxo laminar e bico de Bunsen) durante os procedimentos de preparo da cultura, irradiação, incubação e mensuração da área de inibição; todos os materiais envolvidos foram previamente esterilizados.

\section{RESULTADOS}

Para os oito subgrupos analisados laser 2J, 4J e 6J, TFD 2J, 4J e 6J, azul de metileno e controle - de ambas as bactérias, não foram observados quaisquer halos de inibição e/ou crescimento nas zonas irradiadas, ou seja, das áreas avaliadas em cada placa, todas foram consideradas resistentes, indicando ausência de efeito bactericida e/ou bacteriostático.

\section{DISCUSSÃO}

A literatura é controvertida no que diz respeito aos efeitos do laser sobre crescimento bacteriano. Diversas pesquisas sobre o efeito da radiação laser em bactérias apontam para resultados bioestimulantes ou proliferativos, postulando que tais efeitos se devem às modificações geradas pelo aumento do aporte energético provido pela radiação na cadeia respiratória das bactérias ${ }^{10-13}$.
Pode-se citar como efeitos terapêuticos do laser de baixa potência o [1] efeito proliferativo, que aumenta a neo-angiogênese, síntese de fibroblastos, colágeno e ATP (adenosina trifosfato); [2] efeito fibrinolítico, que facilita a fibrinólise; [3] efeito anti-edematogênico, que facilita o retorno venosolinfático, devido à ação vasodilatadora dos capilares; [4] efeito antiinflamatório, que interfere na síntese de prostaglandinas; [5] efeito analgésico, que libera substâncias quimiotáxicas, que estimulam a liberação de endorfinas; [6] e um possível efeito bactericida, pelo aumento da quantidade de interferon e pelo efeito direto na membrana bacteriana ${ }^{19-22}$.

Pesquisas que evidenciam o efeito bactericida ou bacteriostático da radiação laser relatam que a radiação, absorvida por cromóforos, pode causar mudanças conformacionais em determinadas moléculas, gerando radicais livres e oxigênio reativo os quais, por sua vez, promovem a ruptura de membranas bacterianas ${ }^{9,23}$.

Nussbaum et al..$^{24}$ utilizaram laser de 810 nm, com variação na irradiância de $0,015 \mathrm{~W} / \mathrm{cm}^{2}\left(0-50 \mathrm{~J} / \mathrm{cm}^{2}\right)$ ou 0,03 W/cm² $\left(0-80 \mathrm{~J} / \mathrm{cm}^{2}\right)$, em uma única sessão, em bactérias gram-positivas e gram-negativas, com várias doses. Observaram que para a Escherichia coli houve aumento no crescimento bacteriano $(p=0,01)$, similar nas duas irradiâncias $(p=0,36)$; para a Pseudomonas aeruginosa, quando a irradiância foi baixa o crescimento foi diminuído, comparado ao controle, e quando a irradiância aumentou, a inibição foi maior; finalmente, para o Staphylococcus aureus, para ambas irradiâncias, o crescimento não foi diferente comparado com o controle em qualquer exposição. Relatam aumento no crescimento de Pseudomonas aeruginosa na irradiância de $0,015 \mathrm{~W} / \mathrm{cm}^{2}$ e diminuição em $0,03 \mathrm{~W} / \mathrm{cm}^{2}$, em dose de $1 \mathrm{~J} / \mathrm{cm}^{2}$; sugerem que tal resultado pode ser explicado apenas por diferenças na irradiância e/ ou tempo de exposição, visto que outros fatores foram constantes. No presente estudo, a irradiância utilizada, de 0,03 W/cm², 
em nenhuma das doses produziu os efeitos inibitórios como no estudo de Nussbaum e colaboradores.

Embora a maioria das pesquisas demonstre resultados que convergem para efeitos estimulantes ou inibitórios, os resultados do presente trabalho não apontam para qualquer dessas hipóteses. Os grupos tratados não apresentaram halo de inibição do crescimento bacteriano, evidenciando não haver qualquer efeito bactericida ou bacteriostático do laser utilizado com os parâmetros em questão. Por outro lado, não houve aumento do crescimento bacteriano dos grupos tratados quando comparados ao grupo controle, pois ambos cresceram de forma homogênea. Isso denota que a radiação laser nas doses utilizadas, com comprimento de onda de $670 \mathrm{~nm}$, não provocou efeito bioestimulante sobre as bactérias. Contudo, vale ressaltar que o modo de aplicação, única dose no centro da placa, pode ter sido responsável pela ausência de efeitos sobre o crescimento bacteriano, visto que somente a região central recebeu a aplicação. Além disso, a quantidade de energia entregue nos grupos irradiados pode estar fora da janela terapêutica para o laser de baixa potência. E ainda, visto que a aplicação por zona ocorre sem contato da caneta aplicadora com a placa de cultura, de acordo com Baxter ${ }^{9}$ ocorrerá perda significativa da energia, pois a irradiância, nesse caso, cai devido à lei do quadrado inverso (a intensidade da radiação incidente é inversamente proporcional ao quadrado da distância entre a fonte e a superfície) e ao aumento da reflexão.

A ausência de efeito bactericida no grupo tratado com TFD pode dever-se à concentração extremamente baixa do agente fotossensibilizante utilizado. O azul de metileno foi usado com essa finalidade devido a sua eficácia demonstrada em sensibilizar tais bactérias; além disso, apresenta absorção máxima de energia nas faixas próximas à do laser utilizado $(>620 \mathrm{~nm})^{18}$. Chan e Lai ${ }^{25}$ relatam ter obtido efeitos bactericidas com concentrações dez vezes menores que a usada nesta pesquisa $(0,1 \mu \mathrm{g} / \mathrm{ml})$, porém Teichert et al. ${ }^{16}$ afirmam que a concentração ótima desse fotossensibilizante é de 500 $\mathrm{mg} / \mathrm{ml}$. Em vista dessa discordância, no presente estudo optou-se por uma concentração intermediária de azul de metileno.

O meio de cultura Ágar MuellerHinton foi escolhido por ser o meio ótimo para o desenvolvimento das bactérias em questão, e também pela existência na literatura de trabalhos utilizando tal meio ${ }^{14,15,24}$, embora outras pesquisas utilizem outros meios de cultura $^{16,25,26}$.

Apesar de os resultados deste trabaIho não confirmarem efeitos bactericidas e/ou bacteriostáticos da laserterapia nem da terapia fotodinâmica, ressalta-se que este é um estudo in vitro, com irradiação por zona (o que pode produzir perdas de energia), com doses relativamente baixas de densidade de energia, e em uma única sessão, o que não permite vislumbrar um possível efeito cumulativo do laser de baixa potência (esta é uma prática metodológica comum nesse tipo de estudo ${ }^{10,12-15}$ ). Portanto, fazem-se necessários mais estudos para corroborar os resultados aqui obtidos.

\section{CONCLUSÃO}

Em placas contendo $P$. aeruginosa e $S$. aureus, nem a irradiação de laser de baixa potência $(670 \mathrm{~nm})$, nem a terapia fotodinâmica com azul de metileno, ambas em doses de 2, 4 e $6 \mathrm{~J} / \mathrm{cm}^{2}$, nem o azul de metileno sem laser produziram qualquer alteração no crescimento ou inibição das bactérias.

\section{REFERÊNCIAS}

1 Brook I. Anaerobic and aerobic bacteriology of decubitus ulcers in children. Am Surg 1980;46:624-6.

2 Kontiainen S, Rinne E. Bacteria isolated from skin and soft tissue lesions. Eur J Clin Microbiol. 1987;6:420-2.

3 Saini S, Gupta N, Aparna V, Lokveer, Griwan MS. Surgical infections: a microbiological study. Braz J Infect Dis. 2004;8(2):118-25.

4 Candido LC. Nova abordagem no tratamento de feridas. São Paulo: SENAC-SP; 2001.

5 Sader HS, Mendes RE, Gales AC, Jones RN, Pfaller MA, Zoccoli $C$, et al. Perfil de sensibilidade a antimicrobianos de bactérias isoladas do trato respiratório baixo de pacientes com pneumonia internados em hospitais brasileiros: resultados do Programa SENTRY, 1997 e 1998. J Pneumol. 2001;27(2):59-67.
6 Miller H, Delozier J. Cost implications of the pressure ulcer treatment guideline. Columbia, MD: Center for Health Policy Studies; 1994.

7 Hopkins JT, McLoda TA, Seegmiller JG, Baxter GD. Low-level laser therapy facilitates superficial wound healing in humans: a triple-blind, sham-controlled study. J Athl Train. 2004;39(3):223-9.

8 Vladimirov YA, Osipov AN, Klebanov GI. Photobiological principles of therapeutic applications of laser radiation. Biochemistry (Mosc). 2004;69(1):81-90.

9 Baxter D. Laserterapia de baixa intensidade. In: Kitchen S, editora. Eletroterapia: prática baseada em evidências. 11aㅡ ed. São Paulo: Manole; 2003. p.171-90. 


\section{Referências (cont.)}

10 Kawamoto K, Senda N, Shimada K, Itol K, Hirano Y, Murai S. Antibacterial effect of yellow He-Ne laser irradiation with crystal violet solution on Porphyromonas gingivalis: an evaluation using experimental rat model involving subcutaneous abscess. Lasers Med Sci 2000;15:257-62.

11 Karu TI. Primay and secondary mechanisms of action of visible to near-IR radiation on cells. J Photochem Photobiol B. 1999;49:1-17.

12 Karu TI, Tiphlova AO, Fedoseyeva GE, Kalendo GS, Letokhoy VS, Lobko VV, et al. Biostimulating action of low-intensity monochromatic visible light: is it possible? Laser Chem. 1984;5:19-25.

13 Karu TI, Tiphlova OA, Letokhoy VS, Lobko VV. Stimulation of $E$. coli growth by laser and incoherent red light. Nuovo Cimento. 1983;2(4):1138-44.

14 Nussbaum EL, Lilge L, Mazzulli T. Effects of 630-, 660-, 810-, and 905-nm laser irradiation delivering radiant exposure of $1-50 \mathrm{j} / \mathrm{cm}^{2}$ on three species of bacteria in vitro. J Clin Laser Med Surg. 2002;20(6):325-33.

15 Nussbaum EL, Lilge L, Mazzulli T. Effects of 810-nm laser irradiation on in vitro growth of bacteria: comparison of continuous wave and frequency modulated light. Lasers Surg Med. 2002;31:343-51.

16 Teichert MC, Jones JW, Usacheva MN, Biel MA. Treatment of oral candidiasis with methylene bluemediated photodynamic therapy in an immunodeficient murine model. Oral Surg Oral Med Oral Pathol. 2002;93(2):155-60.

17 Jayasree RS, Gupta AK, Rathinam K, Mohanan PV, Mohanty M. The influence of photodynamic therapy on the wound healing process in rats. J Biomater Appl. 2001;15:176-86.
18 Heckenkamp J, Adili F, Kishimoto J, Koch M, LaMuraglia G. Local photodynamic action of methylene blue favorably modulates the postinterventional vascular wound healing response. J Vasc Surg. 2000;31(6):1168-77.

19 Veçoso MC. Laser em Fisioterapia. São Paulo: Lovise; 1993.

20 Colls J. La terapia laser hoy. Barcelona: Centro de Documentación Laser de Meditec; 1984.

21 Lopes LA. Análise in vitro da proliferação celular de fibroblastos de gengiva humana tratados com laser de baixa potência [dissertação em Engenharia Biomédica]. São José dos Campos: Univap; 1999.

22 Karu TI, Kalendo GS, Letokhoy VS, Lobko VV. Bioestimulation of HeLa cells by low-intensity visible light. Nuovo Cimento. 1982;1(6):828-40.

23 DeSimone NA, Hristiansen C, Dore D. Bactericidal effect of 0.95-mw helium-neon and 5-mw indiumgallium-aluminum-phosphate laser irradiation at exposure times of 30,60, and 120 seconds on photosensitized Staphylococcus aureus and Pseudomonas aeruginosa in vitro. Phys Ther. 1999;79(9):839-46.

24 Nussbaum EL, Lilge L, Mazzulli T. Effects of lowlevel laser therapy (IIlt) of $810 \mathrm{~nm}$ upon in vitro growth of bacteria: relevance of irradiance and radiant exposure. J Clin Laser Med Surg. 2003;21(5):283-90.

25 Chan Y, Lai C. Bactericidal effects of different laser wavelengths on periodontopathic germs in photodynamic therapy. Lasers Med Sci. 2003;18:51-5.

26 Lopes AM, Jardim JR EG, Kina JR. Influência de aplicações do laser Érbio:Yag sobre a viabilidade microbiana. Cienc Odontol Bras. 2004;7(1):75-83. 